\title{
A necessidade dos estudos geográficos em tempos de pandemia
}

\section{Fernando Nadal Junqueira Villela}

Universidade de São Paulo. Faculdade de Filosofia, Letras e Ciências Humanas. São Paulo. Brasil geovillela@usp.br (1) 0000-0002-7804-6565

\section{revista}

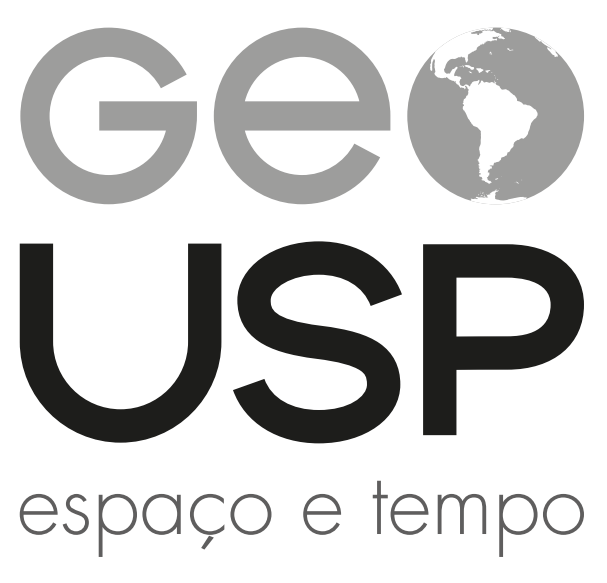

Volume $25 \cdot n^{\circ} 2$ (2021)

ISSN 2179-0892 e-187544

Como citar este artigo:

VILLELA, F N. J. Editorial: a necessidade dos estudos geográficos em tempos de pandemia. Geousp, v. 25, n. 2, e-187544, ago. 2021. ISSN 2179-0892.

Disponível em: https://www.revistas.usp.br/geousp/article/ view/187544. doi: https://doi.org/10.11606/issn.2179-0892. geousp.2021.187544.

\section{(c)}

Este artigo está licenciado sob a Creative Commons Attribution 4.0 Licence 


\section{Editorial \\ A necessidade dos estudos geográficos em tempos de pandemia}

As relações entre os arranjos espaciais dos fenômenos na superfície e suas interações através do tempo sempre fizeram parte dos estudos geográficos. A manifestação das diferenças de produção do espaço, compondo níveis diferenciados de materialidade em contraposição à disposição dos elementos originalmente naturais da paisagem, há muito são investigados por perspectivas multiescalares diversas e pelo método próprio da Geografia, que, entre outros procedimentos, verifica formas, funções, processos e estruturas das organizações espaciais ligadas ao momento histórico ou herdadas de consequências do processo civilizatório.

Essa abordagem geográfica nunca foi tão necessária como nos tempos atuais, em que o surto de Covid-19 tem disseminações muito mais amplas comparadas ao cenário inicial da pandemia, quando ainda não se conheciam as inúmeras variantes do vírus, algumas mais fatais do que as primeiras linhagens. Na tentativa de atenuar a transmissão do vírus em suas diferentes formas, as avaliações logísticas e de planejamento levaram à necessidade de conhecimento das realidades geográficas regionais do país, essas que são diversas, plurais e desiguais, o que expôs a inabilidade dos governantes para reagirem. Preocupados apenas em manter a produção do sistema vigente, é latente o desconhecimento completo dos aspectos relativos à gestão do espaço territorializado, o que não evitou os protestos das camadas sociais frente às consequências mais graves que recaem sobre um grande contingente de excluídos, que, fragilizados pelas complexas contradições da realidade perversa em que vivemos, sofrem muito mais com o quadro atual.

Não faltaram meios para compreender as desigualdades no processo de produção do espaço, a fim de se atenuarem e mesmo evitarem as mais de meio milhão de mortes pela pandemia no país. Há sistemas, dados, tecnologia, monitoramento e procedimentos para tal, onde a mensuração no universo da pesquisa geográfica desenvolve raciocínio interdisciplinar e multiescalar voltado sobretudo aos objetos de estudo da Geografia: espaço, paisagem, território, região e lugar, entre outros. Essas fontes e meios originam-se dos ambientes científicos acadêmicos e institucionais, cujo trabalho há décadas também sofre com os interesses obscuros verticalizantes, que vão desde o desmonte do Estado até a supremacia de uma parcela dominante da sociedade, cujas decisões e ações se manifestam na (des)estruturação espacial da maioria da população, marginalizada pela perpetuação da necropolítica, do racismo, da alienação da cidadania e da estratificação social.

No entanto, devemos nos lembrar de que, mesmo em condições desorganizadas e adversas, o espaço cria a possibilidade de construção de conhecimento pelas pessoas que o habitam, que circulam nele e fazem uso dessa entidade geográfica no devir complexo. Nesse aspecto, os sujeitos ganham em relação aos objetos e interferem nos acontecimentos, redirecionando e amplificando suas consequências, definindo outras lógicas de poder e composições a partir de 
escolhas possíveis. Isso permite que a população se reerga, perceba outros caminhos, mais racionais, na produção do espaço ou que ao menos pleiteiem um espaço mais humanizado e menos mercantil, predatório e perverso. A isso se soma o conhecimento adquirido nos estudos científicos da construção social e espacial, concebendo-se suas composições, objetivos e funções, proporcionando melhor compreensão do momento histórico e dando prioridade à participação dos sujeitos em detrimento de uma engrenagem opressora.

Portanto, mais uma vez, a Geousp contribui com o conhecimento geográfico, disseminando-o por meio de pesquisas de alto nível, em que a fundamentação teórica, o levantamento e a análise de dados e as reflexões decorrentes garantem o avanço cientifico num momento em que ele é tão necessário a nosso país. Boa leitura, e trabalhemos por dias melhores.

Fernando Villela 